\title{
ISOLASI DAN IDENTIFIKASI FUNGI PATOGEN DI KOLAM RENANG KOTA TANGERANG
}

\author{
Makhabbah Jamilatun, Aminah \\ Politeknik Kesehatan Kemenkes Banten \\ Email: makhabbah.j@gmail.com
}

\begin{abstract}
Swimming pool is a public facility that can be used as for recreation and exercise purposes. But the water quality is often left unknown. This research was aimed to isolate and identify the pathogenic fungi from the swimming pool in Tangerang City. It was a descriptive research with laboratory tests. The population in the study was the environment of Tangerang City swimming pool. Samples were taken by purposive sampling at several points of the pool, i.e. the pool water, tap water, shower room water, poolside, toilet wall and floor, and changing room. The results indicated that there was pathogenic fungi contamination in Tangerang City swimming pool. The pathogenic fungi were identified as mold and yeast, found in the swimming pool water: Aspergillus sp., Trichophyton sp.; shower room water: Penicillium sp., Mucor sp.; poolside: Penicillium sp.; toilet wall and floor:Mucor sp., Candida sp.; and changing room: Penicillium sp, Trichoderma sp, Candida sp. The presence of pathogenic fungi in this pool might be caused by contamination of fungal airborne spore, pool users, birds or cats droppings, as well as the temperature and humidity factors that support fungi growth.
\end{abstract}

Keywords : isolation, identification, pathogenic fungi

\section{ABSTRAK}

Kolam renang merupakan fasilitas umum yang dapat digunakan sebagai tempat rekreasi dan wahana berolahraga. Namun air yang digunakan untuk mengisi kolam renang itu sendiri seringkali tidak diketahui kualitasnya. Pada penelitian ini dilakukan isolasi dan identifikasi fungi patogen di kolam renang Kota Tangerang untuk mengetahui cemaran dan jenis fungi patogen di kolam renang tersebut. Jenis penelitian ini deskriptif dengan uji laboratorium. Populasi dalam penelitian adalah lingkungan di kolam renang Kota Tangerang. Sampel diambil secara purposive sampling. Sampel digunakan dalam penelitian ini diambil di beberapa titik yaitu air kolam renang, air kran, air bilas di area kolam renang, tepi kolam renang, serta dinding hingga lantai sekitar toilet, dan ruang ganti. Hasil penilitian ini menunjukkan bahwa terdapat cemaran fungi patogen di kolam renang Kota Tangerang. Fungi patogen tersebut meliputi kapang dan khamir. Fungi patogen ditemukan pada air kolam renang: Aspergillus sp., Trichophyton sp.; air bilas: Penicillium sp., Mucor sp.; tepi kolam renang: Penicillium sp.; toilet :Mucor sp., Candida sp.; ruang ganti: Penicillium sp, Trichoderma sp, Candida sp. Keberadaan fungi patogen di kolam renang ini bisa disebabkan oleh kontaminasi spora fungi di udara, pengguna kolam renang, kotoran burung atau kucing, serta faktor suhu dan kelembaban yang mendukung pertumbuhan fungi.

Kata kunci: isolasi, identifikasi, fungi patogen 


\section{PENDAHULUAN}

Fungi sangat erat hubungannya dengan kehidupan manusia. Fungi bisa hidup dan tumbuh di mana saja baik di lingkungan alam maupun di tubuh manusia yang dapat menyebabkan penyakit bagi manusia itu sendiri. Penyakit yang disebabkan oleh fungi disebut dengan mikosis (Soebono, 2001). Terdapat beberapa jenis mikosis berdasarkan tempat infeksinya pada tubuh manusia, mikosis superfisial, mikosis subkutan dan mikosis profunda. Mikosis superfisial yang biasa dikenal dengan dermatofitosis adalah infeksi fungi dermatofit oleh spesies dari Microsporum, Trichophyton, dan Epidermophyton yang menginfeksi hanya pada jaringan keratin epidermis bagian superfisial (stratum korneum), kuku dan rambut (Yadav et al., 2013; Sowmya, 2014).

Fungi dibagi menjadi bentuk ragi dan kapang. Dari berbagai spesies ragi dan kapang, beberapa diantaranya dapat mengakibatkan mikosis (Irianto, 2013). Fungi patogen sebagian besar bersifat eksogen dengan habitat alami di lingkungan air, tanah dan debris organik. Di lingkungan air, fungi dapat ditemukan baik di sungai, danau, air tanah, badan air lainnya bahkan dalam air laut (Hidayati dkk., 2009; Pindi, 2012). Penelitian yang telah dilakukan oleh Mbata et al., (2008) menunjukkan bahwa terdapat beberapa spesies fungi yang diisolasi dari air sungai seperti Aspergillus sp., Penicillium sp., dan Candida sp. Didukung pula dengan penelitian Noverita (2009) yang menunjukkan bahwa kapang Aspergillus flavus, Aspergillus fumigatus, Candida albicans telah ditemukan dari sungai Ciliwung Jakarta, dimana air di dalamnya digunakan untuk mandi, mencuci, bahkan sumber air minum.

Air sebagai salah satu kebutuhan utama untuk menunjang kehidupan manusia beresiko sebagai perantara penyakit bawaan air (water borne disease). Penyakit tersebut terjadi dengan cara mengkonsumsi air secara langsung maupun pendayagunaan air yang tidak memenuhi standar air bersih (Soemirat, 2003). Salah satu pendayagunaan air antara lain adalah air yang digunakan di kolam renang umum.

Kolam renang merupakan fasilitas umum yang dapat digunakan sebagai tempat rekreasi dan wahana berolahraga. Namun air yang digunakan untuk mengisi kolam renang itu sendiri seringkali tidak diketahui kualitasnya. Dengan demikian air di kolam renang tidak luput dari kontaminasi mikroorganisme termasuk fungi yang merupakan penghuni asli dalam badan air dan beberapa spesies diantaranya berperan sebagai patogen oportunistik pada manusia. Dalam penelitian yang dilakukan 
oleh Fadaei, et.al. (2015), menyebutkan bahwa kesalahan pengelolaan kolam renang dapat menyebabkan kualitas air di dalamnya mudah tercemar mikroorganisme, diantaranya spesies dari fungi seperti Aspergillus sp., Penicillum sp., Nocardia sp., Cladosporium sp., Rhizopus sp., Fusarium sp., dan Mucor sp. Faktor penting yang berperan dalam penyebaran mikosis adalah kondisi kebersihan lingkungan (Yosella, 2015). Oleh karena itu diperlukan pengawasan dan perhatian tentang kualitas air kolam renang yang bertujuan untuk mencegah penurunan kualitas dan penggunaan air yang dapat mengganggu dan membahayakan kesehatan. Sehingga diharapkan rantai penularan penyakit pada pengunjung melalui air di kolam renang akan terputus. Berdasarkan latar belakang tersebut, maka dalam penelitian ini dilakukan isolasi dan identifikasi fungi patogen di kolam renang Kota Tangerang.

\section{METODE}

Penelitian ini dilaksanakan pada bulan November - Desember 2016. Sampel diambil dari lingkungan di kolam renang Kota Tangerang secara purposive sampling. Sampel diambil di beberapa titik yaitu air kolam renang, air kran, air bilas di area kolam renang, tepi kolam renang, serta dinding hingga lantai sekitar toilet, dan ruang ganti.
Pengambilan sampel dilakukan dengan cara air kolam renang dimasukkan ke dalam botol steril sebanyak $100 \mathrm{ml}$ secara aseptis. Untuk sampel dari lingkungan kolam renang dilakukan dengan metode swab (usap). Kemudian sampel dibawa ke Laboratorium Mikrobiologi Jurusan Analis Kesehatan Poltekkes Kemenkes Banten.

Isolasi dan Identifikasi Fungi Patogen

Sampel air sebanyak $0,1 \mathrm{~mL}$ dipipet dengan menggunakan pipet ukur ke dalam medium SDA yang telah ditambahkan antibiotik dengan metode tuang. Lalu diratakan dengan menggunakan batang segitiga pada permukaan plate SDA. Sedangkan sampel dari lingkungan dilakukan dengan mengusap secara menyeluruh dipermukaan media SDA. Cawan petri yang sudah ditanami sampel, dibungkus dengan kertas kopi dan dimasukkan ke dalam inkubator. Sampel diinkubasi selama $3-7$ hari pada suhu kamar. Selanjutnya untuk mengamati perkembangan dan pertumbuhan, kapang ditanam pada slide kultur dan dilakukan pewarnaan dengan lactophenol cotton blue (LPCB). Kapang yang tumbuh diamati di bawah mikroskop. Kapang diidentifikasi secara mikroskopis berdasarkan morfologi, hifa, konidia dan konidioforanya, serta makroskopis berdasarkan ciri koloni.

Data hasil penelitian disajikan secara deskriptif dalam bentuk tabel ataupun gambar. 


\section{HASIL DAN PEMBAHASAN}

Tabel1. Jenis Fungi Patogen yang diisolasi dari Kolam Renang Kota Tangerang

\begin{tabular}{|c|c|c|}
\hline \multirow[t]{2}{*}{ Lokasi Pengambilan Sampel } & \multicolumn{2}{|c|}{ Kelompok Fungi } \\
\hline & Kapang & Khamir \\
\hline \multirow[t]{3}{*}{ Air Kolam Renang } & Aspergillus niger & - \\
\hline & Aspergillus flavus & \\
\hline & Trichophyton rubrum & \\
\hline Air Kran & - & - \\
\hline \multirow[t]{2}{*}{ Air Bilas } & Penicillium $\mathrm{sp}$ & - \\
\hline & Mucor sp & \\
\hline Tepi Kolam Renang & Penicillium $\mathrm{sp}$ & - \\
\hline Toilet (Lantai dan Dinding) & Mucor sp & Candida $\mathrm{sp}$ \\
\hline Ruang Ganti (Lantai dan & Penicillium $\mathrm{sp}$ & Candida sp. \\
\hline Dinding) & Trichoderma $\mathrm{sp}$ & \\
\hline
\end{tabular}
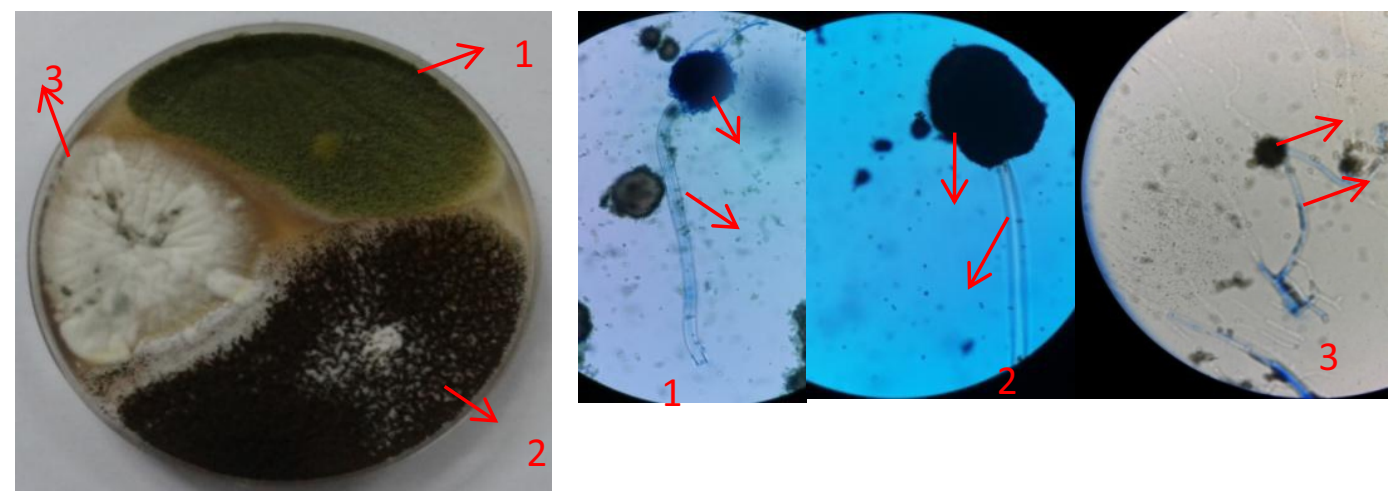

Gambar 1. (A) Bentuk makroskopik Aspergillus sp. pada media SDA. (B). Bentuk mikroskopik Aspergillus sp. dengan: a.konidia; b.konidiofor
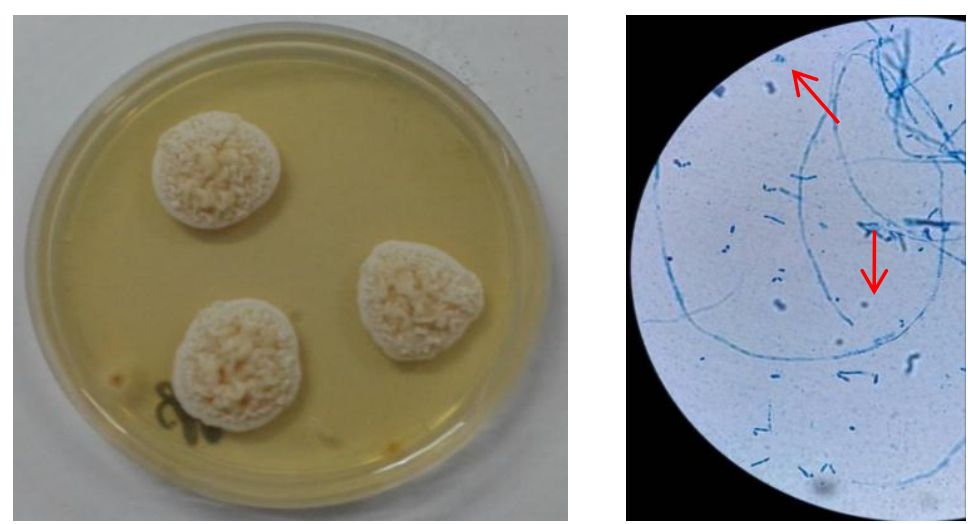

Gambar 2. (A) Bentuk makroskopik Tricophyton rubrum pada media SDA. (B). Bentuk mikroskopik Tricophyton rubrum sp. dengan: a.hifa; b.mikrokonidia 

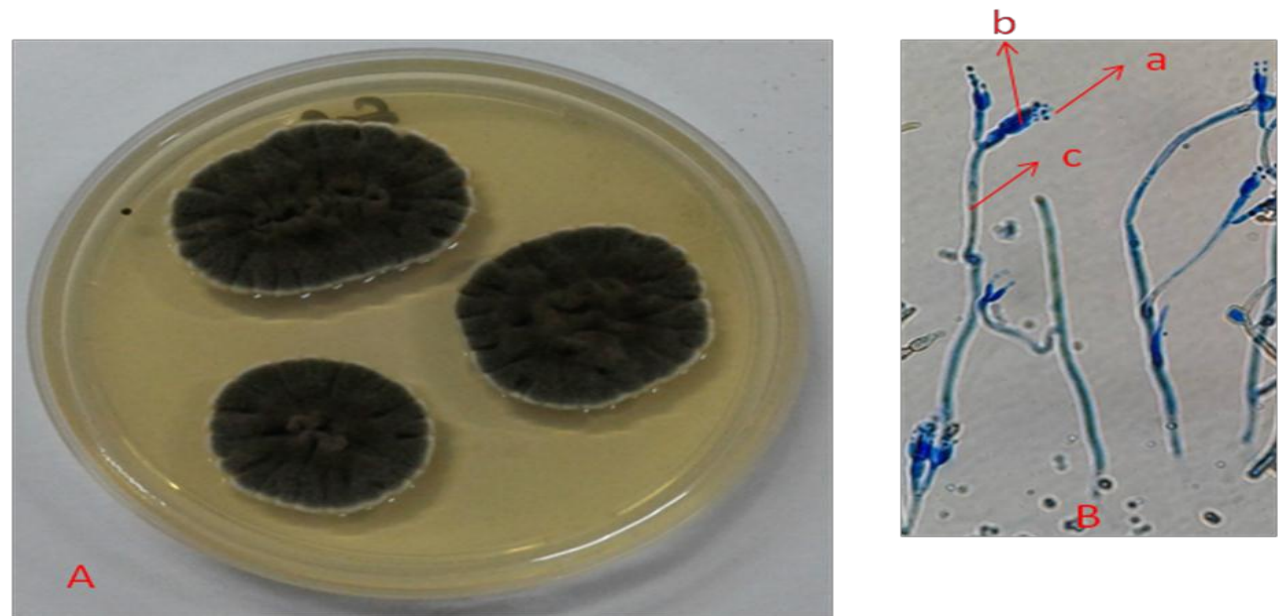

Gambar 3. (A) Bentuk makroskopik Penicillium sp. pada media SDA. (B). Bentuk mikroskopik Penicillium sp. dengan: a.konidia; b.sterigmata; c.konidiofor
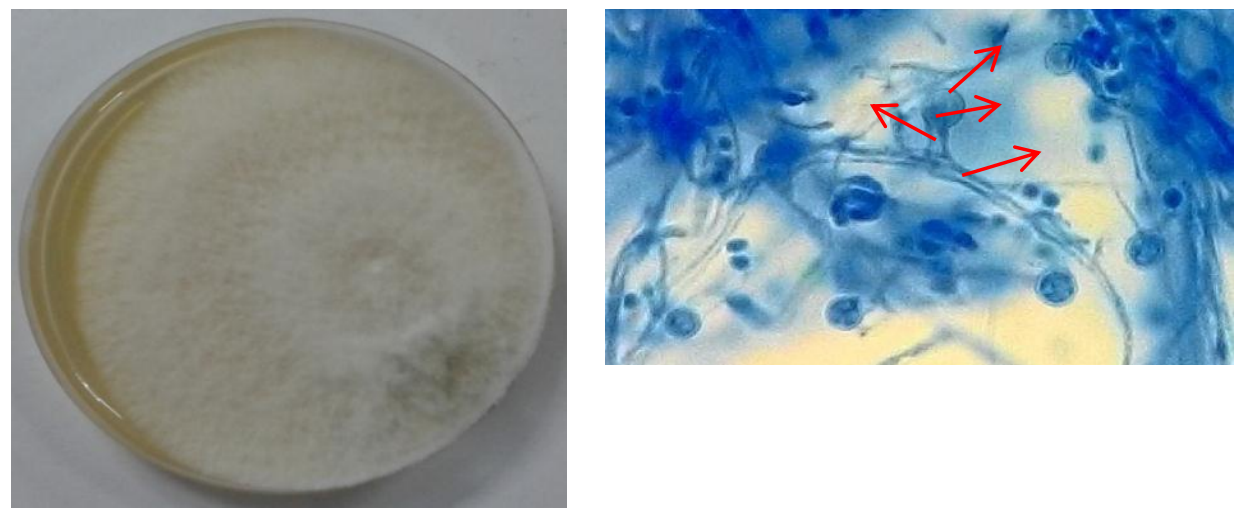

Gambar 4. (A) Bentuk makroskopik Mucor sp. pada media SDA. (B). Bentuk mikroskopik Mucor sp. dengan: a.sporangium; b.kolumela; c.sporangiofor; d.hifa

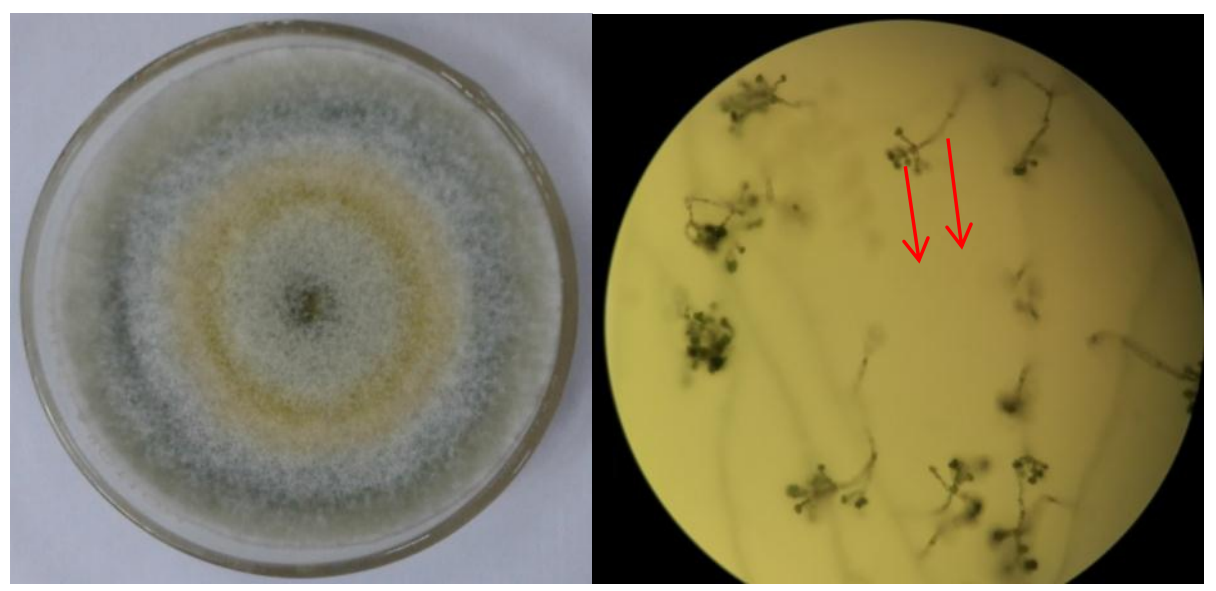

Gambar 5. (A) Bentuk makroskopik Trichoderma sp. pada media SDA. (B). Bentuk mikroskopik Trichoderma sp. dengan: a.konidia; b.konidiofor 


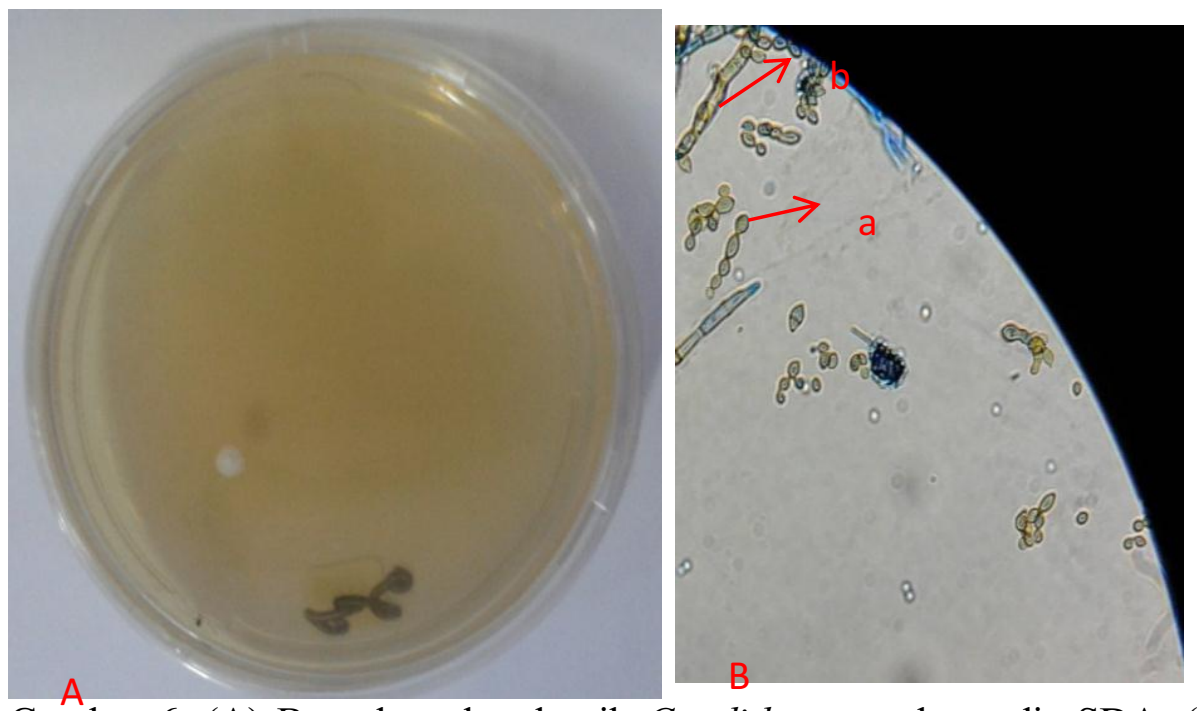

Gambar 6. (A) Bentuk makroskopik Candida sp. pada media SDA. (B). Bentuk mikroskopik Candida sp. dengan: a.blastospora; b.pseudohifa

Berdasarkan hasil pengujian laboratorium menunjukkan bahwa dari sampel yang diperoleh dari area kolam renang ditemukan beberapa jenis fungi patogen. Fungi patogen ditemukan pada sampel yang diambil dari air kolam renang, air bilas, tepi kolam renang, toilet dan ruang ganti, sedangkan pada air kran tidak ditemukan.

Fungi patogen yang ditemukan pada penelitian ini meliputi kapang dan khamir. Kapang terdiri dari Aspergillus niger, Aspergillus flavus, Trichophyton rubrum, Penicillium sp., Mucor sp., Trichoderma sp. dan khamir yaitu Candida sp. Hasil penelitian ini sesuai dengan beberapa penelitian sebelumnya. Penelitian yang telah dilakukan Sima et al. (2012), menunjukkan bahwa Candida sp, Trichophyton sp sering ditemukan di ruang ganti serta di permukaan lingkungan sekitar kolam renang. Begitu juga dengan fungi lain seperti Penicillium sp dan Aspergillus sp. Dan pada penelitian oleh Indabawa et al. (2015), telah diisolasi Aspergillus sp. dari air kolam renang.

Pada sampel air kolam renang ditemukan beberapa fungi patogen yaitu Aspergillus niger, Aspergillus flavus, dan Trichophyton rubrum. Hal ini sesuai dengan penelitian Sheikh and Mughal (2012) yang menemukan fungi Penicillium sp., Rhizopus sp. dan Aspergillus sp. pada air kolam renang di Pakistan. Beberapa penulis melaporkan Tricophyton sp. sebagai agen etiologi dari dermatofitosis 
yang merupakan spesies anthropophilic dan menyebabkan penyakit kronis pada manusia (Ali et al., 2012).

Menurut EPA (2011), keberadaan mikroorganisme tersebut di dalam air kolam renang disebabkan air kolam renang bisa menjadi muara bagi mikroorganisme patogen dari perenang yang terinfeksi atau dari sumber air yang terkontaminasi atau dari kontaminasi udara atau dari pengobatan air kolam yang tidak efektif. Dalam banyak kasus penyakit terkait dengan kontaminasi feses dalam badan air, kontaminasi mikroorganisme dikarenakan kotoran yang dikeluarkan oleh perenang atau sumber air yang terkontaminasi kotoran hewan seperti burung dan hewan pengerat (WHO, 2008).

Pada sampel air bilas ditemukan fungi Penicillium sp. dan Mucor sp. Keberadaan fungi ini bisa disebabkan oleh sumber air yang terkontaminasi atau spora fungi yang berasal dari udara dan menempel pada permukaan saluran air, sehingga mengkontaminasi air bilas. Pada lingkungan kolam renang ditemukan beberapa kapang dan yeast. Hal ini sesuai dengan penelitian yang telah dilakukan oleh Rafiei et al., (2010) yang telah mengisolasi kapang dan yeast dari lingkungan di sekitar kolam renang. Pada penelitian ini, Penicillium sp. di isolasi dari tepi kolam renang dan ruang ganti. Mucor sp. diisolasi dari toilet. Candida sp. diisolasi dari toilet dan ruang ganti. Selain itu, di ruang ganti juga ditemukan Trichoderma sp. yang merupakan fungi saprofit yang kehadirannya bisa berbahaya pada kondisi tertentu bagi host immunnocompromised dan menyebabkan infeksi dari spora jamur seperti alergi (Indabawa et al., 2015). Menurut Nanbakhsh et al. (2004), fungi seperti Penicillium sp., Rhizopus sp., Candida sp., sering diisolasi dari tepi kolam renang, toilet dan ruang ganti, serta tempat-tempat lain di luar kolam renang. Kehadiran fungi tersebut disebabkan kontaminasi terus menerus oleh spora fungi melalui udara, tanah, dan tubuh manusia. Kontaminasi di sekitar lingkungan kolam renang bisa berasal dari partikel jamur dari perenang yang terinfeksi yang beraktifitas di sekitar kolam renang (Rafiei et al., (2010)). Kapang dan khamir yang ditemukan tersebut memiliki potensi patogenesitas untuk kandidiasis, otomycosis, asma dan alergi. Beberapa fungi patogen tersebut di atas tumbuh di sekitar kolam renang karena didukung kondisi pertumbuhan yang baik. Lingkungan fisik kolam renang sangat lembab dan hangat, yang membuatnya menjadi lingkungan yang sesuai untuk penyebaran dan pertumbuhan fungi. Sebagian besar fungi, seperti Aspergillus sp., Penicillium sp., Mucor sp., 
dan Rizopus sp. tumbuh dengan mudah di lingkungan lembab dan hangat (Rafiei et.al., 2010). Selain itu, fungi hanya dapat membentuk sporangium apabila kelembaban udara lebih dari 91\%, dan paling baik bila kelembaban udara 100\%. Faktor lain yang mempengaruhi tumbuhnya fungi diantaranya adalah suhu. Menurut Fadaeifard (2011) fungi perairan dapat tumbuh optimum pada suhu 15$30^{\circ} \mathrm{C}$. Pada umumnya suhu di sekitar kolam renang berkisar antara $23-31{ }^{\circ} \mathrm{C}$, sehingga fungi dapat tumbuh dengan baik. Selain tersebut di atas, secara umum keberadaan fungi disekitar kolam renang bisa disebabkan oleh kurangnya kebersihan orang yang mandi di kolam dan kurangnya pengetahuan akan kesehatan sanitasi pada air kolam renang dan lingkungan di sekitarnya. Oleh karena itu para pengunjung kolam renang hendaknya meningkatkan kebersihan pribadi serta perilaku higienis, begitu juga dengan pengelola kolam renang untuk dapat meningkatkan dan terus memantau kualitas air dan lingkungan kolam renang.

\section{SIMPULAN}

Terdapat cemaran fungi patogen di kolam renang Kota Tangerang. Fungi patogen di kolam renang Kota Tangerang meliputi kapang dan khamir. Kapang terdiri dari Aspergillus niger, Aspergillus flavus,
Trichophyton rubrum, Penicillium sp., Mucor sp., Trichoderma sp. dan khamir yaitu Candida sp.

\section{DAFTAR RUJUKAN}

Ali Zarei M., Sara R.. 2012. Dermatophytic contaminations in sport centres of Jundishapur University of Medical Sciences, Ahvaz, Iran. Turk $J$ Med Sci. 2012; 42 (1): 177-178

EPA (Environmental Protection Agency). 2011. Bacteria water quality, standards for recreational waters (Fresh and marine waters) pp. 123145.

Fadei, A. and Masoud A. 2015. Comparison of Chemical, Biological. And Physical Quality Assessment of Indoor Swimming Pools in Shahrekord City, Iran in 2013. Global Journal of Helath Science. Vol.7, No.3: 240-248.

Fadaeifard, F., M. Raissy., H. Bahrami., E. Rahimi., A. Najafipoor. 2011. Freshwater Fungi Isolated from Eggs and Broodstocks with an Emphasis on Saprolegnia in Rainbow trout Farms in West Iran. Journal of Microbiology Research. 4(22):3647- 3651.

Hidayati NA, Suyoso S, Hinda D, Sandra E. Mikosis superfisialis di divisi mikologi unit rawat jalan penyakit kulit dan kelamin rsud dr. Soetomo surabaya tahun 2003-2005. Surabaya: Department Kesehatan Kulit dan Kelamin Fakultas Kedokteran Universitas Airlangga. 2009; 21(1)1-8.

Indabawa I.I., Ali S. and M.D Mukhtar. 2015. Assessment of Microbiological and Physico-Chemical Quality of Some Swimming Pools within Kano Metropolis, Kano Nigeria. rd International Conference on Biological, Chemical \& Environmental Sciences (BCES-2015) Sept. 21-22, 
2015 Kuala Lumpur (Malaysia).

Mbata, T.I., S.I Ogiehor and M.N Obeleagu. 2008. Isolation of filamentous fungi from YardenitBaptismal site on the Jordan River. Sudanese Journal of Public Health. Vol.3 (4) 173

Nanbakhsh,H. K Diba, K Hazarti. 2004. Study of Fungal Contamination of Indoor Public Swimming Pools. Iranian J Publ Health, Vol. 33, No. 1, pp.60-65.

Noverita, 2009. Identifikasi Kapang Dan Khamir Penyebab Penyakit Manusia Pada Sumber Air Minum Penduduk Pada Sungai Ciliwung Dan Sumber Air Sekitarnya. VIS VITALIS, Vol. 02. No. 2

Pindi, Pavan Kumar. 2012. Diversity of fungi at various depths of marine water. Research in Biotechnology, 3(4): 62-66, 2012.

Rafiei A, Amirrajab N. 2010. Fungal Contamination of Indoor Public Swimming Pools, Ahwaz, South-west of Iran. Iran J Publ Health 39: 124128.

Soemirat, J. ; 2003. Toksikologi lingkungan. Yogyakarta. Gadja Mada University.
Sowmya Nasimuddin, Appalaraju B, Surendran P, Srinivas CR. 2014. Isolation, Identification and comparatative analysis of SDA and DTM for dermatophytes from clinical samples in a tertiary care hospital. IOSR Journal of Dental and Medical Sciences (IOSR-JDMS). Volume 13, Issue 11 Ver. II (Nov. 2014)

Sima Rasti, Mohammad Ali Assadi, Leila Iranshahi, Mahmood Saffari, Hamid Reza Gilasi, Mohammad Pourbabaee. 2012. Assessment of Microbial Contamination and Physicochemical Condition of Public Swimming Pools in Kashan, Iran. Jundishapur $J$ Microbiol. 2012; 5(3):450-455. DOI: $10.5812 / \mathrm{jjm} .2478$.

WHO (World Health organization). 2008. Guidelines for Drinking water Quality. 3rd Edition, Incorporating the first and second edition vol. 1 .

Yadav A, Urhekar AD, Mane V, Danu MS, Goel N, Ajit KG. Optimization and isolation of dermatophytes from clinical samples and in vitro antifungal susceptibility testing by disc diffusion method. Journal of Microbiology and Biotechnology. 2013; 2(3)19-34.

Yosella, T. 2015. Diagnosis and Treatment of Tinea cruris. J Majority. Volume 4 Nomor 2: 122 
